\title{
The oyster vasa-like gene: a specific marker of the germline in Crassostrea gigas
}

\author{
Caroline Fabioux ${ }^{\mathrm{a}},{ }^{\mathrm{b}}$, Stéphane Pouvreau ${ }^{\mathrm{a}}$, Frédérique Le Roux ${ }^{\mathrm{c}}$ and Arnaud Huvet ${ }^{\mathrm{a}^{\star}}$ \\ a UMR Physiologie et Ecophysiologie des Mollusques Marins, Ifremer, Centre de Brest, B.P.70, 29280, Plouzané, \\ France \\ b UMR CNRS 6539, Laboratoire des Sciences de l'Environnement Marin, Université de Bretagne Occidentale, \\ IUEM, 29280, Plouzané, France \\ c Laboratoire de Génétique et Pathologie, Ifremer, 17390, La Tremblade, France \\ * ahuvet@ifremer.fr Fax: +33-2-98-22-46-53
}

\begin{abstract}
The vasa gene is a key determinant for germline formation in eukaryotes. This gene, highly conserved through evolution, encodes a RNA helicase protein member of the DEAD-box family. To understand the germline formation in oyster, we report here the isolation and the characterization of a vasa orthologue in Crassostrea gigas (Oyvlg). OyVLG contained the eight consensus domains of the DEAD-box including those providing RNA unwinding activity. The expression pattern of Oyvlg was examined in adult oyster tissues at different reproductive stages. Its expression was restricted to germline cells both in males and females, including germinal stem cells and auxiliary cells. The expression of Oyvlg, strongest in early germ cells, decreased as the maturation proceeded. These data and the evolutionary conservation observed suggested the role of Oyvig in germline development. Oyvlg is the first germ cell specific marker in oyster and will be very useful in studies of oyster germline formation.
\end{abstract}

Keywords: Author Keywords: Oyster; Gametogenesis; Germline; vasa; DEAD-box; RNA helicase 


\section{Introduction}

Sexual reproduction has been highly conserved through evolution. The germ cells are essential for maintenance of countless sexually reproducing species through generations. The origin and nature of the germline have long been known in model organisms. In eukaryotes, gametes are derived from primordial germ cells (PGCs) that arise early during embryogenesis [1]. In most animals, the PGCs diverge early from the somatic cell lineage. They proliferate and migrate to the developing gonad of embryos by complex processes. In preadult gonad, PCGs become germline stem cells (GSCs) [1,2]. When organisms reach sexual maturity, stem cells differentiate into germ cells that undergo meiosis to form functional gametes.

In bivalve molluscs and especially in the oyster Crassostrea gigas, data on origin and development of the germline are very incomplete. In an aquaculture context, the knowledge of these processes will facilitate greater control of the reproduction of $C$. gigas, something that still is based largely on empirical techniques [3]. Up to now, information on germ cells formation in oysters was derived from histological and cytological studies [4]. General data indicate that future germ cells can be detected from the post-larval stage in most mollusc species by their characteristic morphology [4]. However, PGC have never been observed in oyster larvae. In juvenile and adult oysters, gonad constitutes a network of tubules interspersed in connective tissue and surrounding the digestive gland [4]. Different germ cell developmental stages can occur simultaneously in the gonad: undifferentiated cells, growing germ cells and mature gametes. It is unclear, however, whether these represent one cohort of germ cells with asynchronous development, or multiple cohorts of germ cells, each with synchronous development. The gonad of oyster is not permanent and the processes of annual gonad restoration are still unclear. Previous hypothesis, based on electronic microscopy on M. edulis and cell culture on M. edulis and C. gigas, suggested that germ cells differentiate from the epithelial cell region, but without any data on the origin of these cells. 
Several studies pointed out the central role of the vasa gene in germ cell development. This gene was first characterized in Drosophila melanogaster [5,6], and vasa related genes have since been isolated from many invertebrates and vertebrates, including Caenorhabditis elegans [7], Hydra magnipapillata [8], Ciona intestinalis [9], Xenopus laevis [10], Danio rerio [11], Mus musculus [12], and Homo sapiens [13]. Vasa gene encodes a protein member of the DEAD-box family [5]. All DEAD-box proteins are putative ATP-dependant RNAhelicases [14]. Vasa is specifically expressed in germ cells in all these organisms and is required for germline development [6]. In Drosophila, vasa is expressed at two different stages: first, in embryos, corresponding to a maternal expression for the localisation of the cytoplasmic determinants to the formation of germline, and later during early oogenesis and spermatogenesis, for the development of oocytes and spermatocytes [15].

In this paper, we report the isolation and the molecular characterization of a vasa-like gene in C. gigas, and the analysis of its spatial and temporal expression along a reproductive cycle under experimental conditions. As no marker of germ cells has been reported yet in oysters, the Oyvlg is useful as a germ cell lineage marker and will contribute to knowledge of germline development and regulation of reproduction in C. gigas.

\section{Material and methods}

\section{Biological material}

Oyster larvae were produced in the Ifremer hatchery in La Tremblade (France) from 30 wild broodstocks collected in the Marennes-Oléron Bay. Spat were then reared at the Ifremer station in Bouin (France). One-year-old oysters were then kept at the Ifremer shellfish laboratory in Argenton (France) from February 2002 to March 2003 for the experiment. Oysters were placed in 300-L raceways in $20 \mu \mathrm{m}$-filtered seawater and fed with a diet of three algae species with a ratio equal to $8 \%$ dry weight algae/dry weight oyster per day and per 
oyster (33\% Chaetoceros calcitrans and Skeletonema costatum, 33\% T-Isochrysis galbana, 33\% Tetraselmis chui). Temperature and photoperiod conditions applied to the experimental raceways were modelled on mean natural cycles measured at Marennes-Oléron Bay.

\section{Total RNA extraction}

For total RNA extraction, 50-mg pieces of 6 organs (gills, mantle, adductor muscle, labial palps, gonad and digestive gland) were isolated from male and female oysters in maturation and placed in $500 \mu \mathrm{l}$ of extraction solution (4 M guanidium thiocyanate, $25 \mathrm{mM}$ sodium citrate $\mathrm{pH}$ 7, $0.5 \%$ lauryl sarcosyl, $0.1 \mathrm{M} \beta$-mercaptoethanol). Total RNA was extracted by the acid guanidium thiocyanate-phenol-chloroform method of Chomczynski and Sacchi [16] and treated with 0.1 unit/ $\mu \mathrm{L}$ DNase I (deoxyribonuclease) (Sigma). RNA concentrations were measured, after DNase treatment, at $260 \mathrm{~nm}$ using the convertion factor $1 \mathrm{OD}=40 \mu \mathrm{g}$ RNA.

\section{Reverse transcription-polymerase chain reaction, cloning, sequencing}

Reverse transcription (RT) was carried out as described in Huvet et al. [17] using oligo(dT) $)_{23}$-anchored as primer, 200 units Moloney Murine Leukemia Virus reverse transcriptase (Sigma) and $2 \mu$ g total RNA from female growing oocytes, mantle, gills, labial palps, adductor muscle, and digestive gland. Degenerated primers VAS A (5' ATGGCNTGYGCNCARACNGG 3') and VAS E (5' GGCATRTCRTARTTDATNACRTG 3') were designed based on conserved VASA protein sequences from Drosophila, Caenorhabditis, Xenopus, zebrafish and mouse. Polymerase chain reaction (PCR) was performed in a total volume of $100 \mu \mathrm{l}$ with $1 \mu \mathrm{g}$ of cDNA, $0.2 \mathrm{mM}$ each dNTP, $0.2 \mu \mathrm{M}$ each of VAS A and VAS E, 1.5 mM MgCl $2,1 X$ Taq buffer and 0.5 unit of Taq DNA polymerase (Qbiogène). Amplification was performed for 30 cycles at $94^{\circ} \mathrm{C}$ for $1 \mathrm{~min}, 50^{\circ} \mathrm{C}$ for $1 \mathrm{~min}, 72^{\circ} \mathrm{C}$ for $1 \mathrm{~min}$ and a final extension step at $72^{\circ} \mathrm{C}$ for $5 \mathrm{~min}$. The PCR products were electrophoresed on $1 \%$ 
$(\mathrm{w} / \mathrm{v})$ agarose gel in $1 \mathrm{X}$ TAE buffer (TAE: Tris, acetic acid, 0.5 M EDTA) and stained with ethidium bromide. PCR products of expected size were gel-extracted (QIAquick ${ }^{\circledR}$ Gel Extraction Kit, Qiagen), cloned with a TOPO-TA cloning ${ }^{\circledR}$ kit (Invitrogen) and then sequenced (Qbiogène).

5' and 3' regions of the transcript were identified from partial cDNA using gene-specific primers with the SMART RACE cDNA Amplification Kit (BD Biosciences). Two reactions were performed for each 5' and 3' end. Primers used for 5' and 3' end amplifications were VSAS10 (5' CTTGTGGTTCCTGGACCTCGGAGA 3'), VS-AS11 (5' TGGACCTCGGAGAAACTACTGCCACT 3') and VS-S10 (5' GGAAGAAGCTC TGCGCGATTTCAAGA 3'), VS-S11 (5' AGTATGCCAGGAGCTGGGTATG 3'), respectively. PCR products were analysed by electrophoresis as described above. Fragments of largest size were excised and gel-extracted using the QIAquick ${ }^{\circledR}$ Gel Extraction Kit (Qiagen), subcloned with a TOPO-TA cloning ${ }^{\circledR}$ kit (Invitrogen), and then sequenced.

Tissue distribution of presumptive oyster vasa mRNA was investigated by RT-PCR with specific primers VS-S9 (5' TCCCCGAGGAGATTCAGA 3') and VS-AS9 (5' ACGTCAGTGCAAGCACCA 3'). Primers Felongf (5' ACCACCCTGG TGAGATCAAG 3') and Felongr (5' ACGACGATCGCATTTCTCTT 3') were designed from reference sequence [18] and used to amplify the transcript of the constitutively expressed elongation factor protein of C. gigas as positive control. Total RNA from various tissues of male and female oysters was isolated and cDNA synthesis was performed as described above. PCR reaction was performed with $25 \mathrm{ng}$ of template cDNA, $0.2 \mathrm{mM}$ each dNTP, $0.2 \mu \mathrm{M}$ each specific primer VS-S9 and VS-AS9 or Felongf and Felongr, $1.5 \mathrm{mM} \mathrm{MgCl}_{2}$, $1 \mathrm{X}$ Taq buffer and 0.5 unit of Taq DNA polymerase (Qbiogène). Amplification was performed as described above except that the annealing temperature was $60^{\circ} \mathrm{C}$. The amplified products were electrophoresed on a $2 \%(\mathrm{w} / \mathrm{v})$ agarose gel. 


\section{Phylogenetic analysis}

Phylogenetic analysis were realised with a range of DEAD-box proteins belonging to VASA, PL10 or GLH sub-families, from vertebrates and invertebrates. The sequences were aligned using CLUSTAL W. An unrooted distance base phylogenetic tree was constructed in PHYLIP using the unweight pair group method with arithmetic mean (UPGMA). One thousand bootstrap trials were run using the neighbour-joining algorithm for each node.

\section{Histology}

For histological examination, 15 oysters were randomly sampled at five different stages of the annual reproductive cycle: (1) the initiation of the reproductive cycle, (2) the maturation step, (3) the end of maturation, (4) post-spawning, and (5) the resting period. Cross sections (3-mm large) of the visceral mass were realised above the pericardic region for each oyster after that adductor muscle, gills and mantle were remote. These sections were fixed in Davidson's solution (12\% glycerine, 22\% formaldehyde 37\%-40\%, 33\% ethanol $95^{\circ}$, 33\% 0.2 $\mu \mathrm{m}$-filtered seawater, $1 / 9$ (v/v) acetic acid added just before use) $\left(4^{\circ} \mathrm{C}, 48\right.$ hours). Sections were dehydrated in ascending ethanol series, cleared with xylene, and embedded in paraffin. Sections $5 \mu \mathrm{m}$ thick were cut, mounted on glass slides, stained with Harry's hematoxylinEosin Y [19], and coverslipped. Slides were examined under a light microscope.

In addition, the mean occupation rate of the gonad relative to the total surface of the visceral mass was determined by image analysis software (IMAQ Vision Builder, National Instrument).

\section{In Situ Hybridization}

In situ hybridization was realised on $5 \mu \mathrm{m}$-histological sections of the whole oysters and of the visceral mass (without gill, mantle, and adductor muscle) on the same samples than 
those used for histological analysis. Sense and antisense DNA probes complementary to presumptive oyster vasa gene cDNA were synthesised. cDNA extracted from maturing female oocytes was used as template for PCR amplifications using three primer pairs: VSS1/VS-AS2 (5' TCCAGGAACCACAAGCCCTG 3'/ 5' GATGTCTGGACC GAAACCCA 3'); VSS2/VS-AS3 (5' TGGGTTTCGGTCCAGACATC 3'/5' CTCTGAACCCGTCT CTGTGA 3') and VSS3/VS-AS4 (5' TCACAGAGACGGGTTCAGAG 3'/5' CTGGAGCTTTCCCA AGCTTG 3'). PCR reactions proceeded as described above except that the annealing temperature was $52^{\circ} \mathrm{C}$. In situ hybridization reactions were performed according protocol described by Montagnani et al. [20]. Slides were analysed using a light microscope.

\section{Results}

Isolation of the oyster vasa orthologue cDNA

A single fragment of expected size (757 bp) was amplified from female gonad by RTPCR with degenerated primers VAS A and VAS E and the 5' and 3' ends of this sequence were obtained by RACE-PCR. The total isolated sequence of 3088 bp (Figure 1) comprised an open reading frame (ORF) of 2277 bp, a stop codon (TAA), and a 3' untranslated region (UTR) of $811 \mathrm{bp}$. The deduced amino acid sequence is 759 aa long and contains the eight consensus sequences characteristic of the DEAD-box protein family [5,14]. The N-terminal region is glycine $(\mathrm{G})$ rich (36\% in residues 1-239) and contains three arginine-glycine-glycine (RGG) motifs (Figure 1). In the C-terminal region, six of the eight last amino acids are acidic residues (glutamate $\mathrm{E}$ and aspartate $\mathrm{D}$ ). The predicted amino acid sequence in oyster closely matches VASA-related proteins. Identity rates were highest when compared with VASArelated proteins like in Drosophila (45\%), in zebrafish (49\%), in mouse (50\%), and in Ciona (59\%) than those observed in comparisons with other DEAD-family proteins, like p68 in human (34\%) or PL10 in mouse (42\%) [21,22]. The analysis of phylogenetic relationships between members of DEAD-box protein family showed three distinct clusters [11]: the 


\section{VASA sub-family including the presumptive oyster VASA sequence, the PL10 sub-family}

\section{and the GLH sub-family (Figure 2).}

Figure 1. Nucleotidic sequence of the cDNA and deduced amino acid sequence of Oyvlg. Grey highlighted sequences are the eight conserved regions of the DEAD-box protein family. Acidic amino acids in C-terminal region are indicated by asterisks. Glycine residues in N-terminal region are underlined. Arginine-glycine-glycine motifs are double underlined.

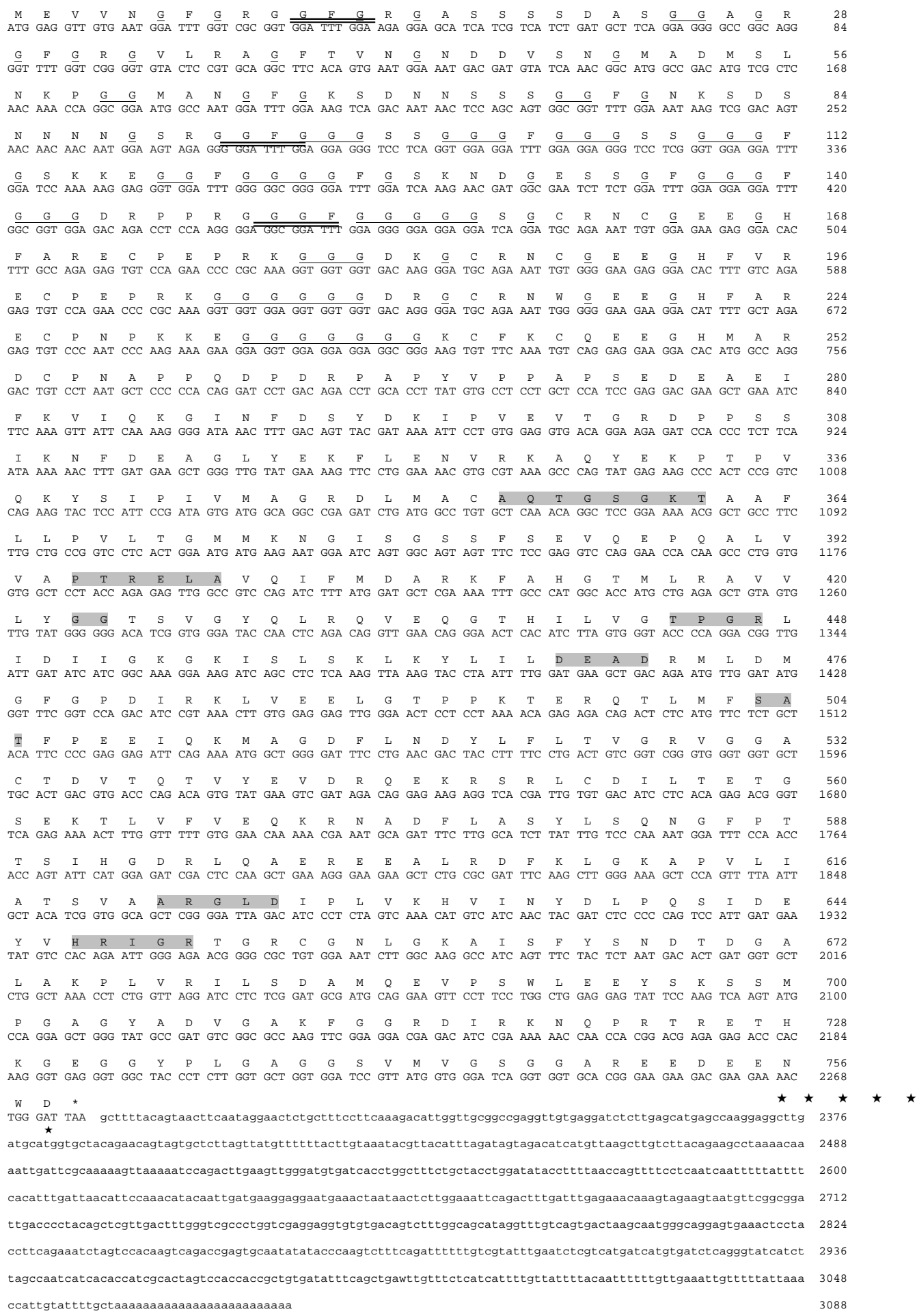


Figure 2. Graphical representation of phylogenetic analysis of VASA-related proteins. Sequence alignment was realised using CLUSTAL W. From this alignment a distance based phylogenetic tree was constructed using the UPGMA (unweight pair group method with arithmetic mean). One thousand bootstrap trials were run using the neighbour-joining algorithm. Number at each node represents the percentage values given by bootstrap analysis. Genbank accession numbers of sequences are indicated in brackets in bold underlined. MVH M. musculus

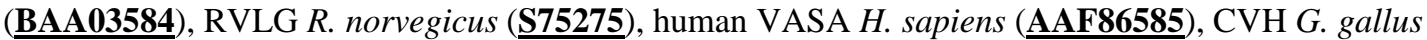
(BAB12337), XVLG X. laevis (吕C03114), VLG D. rerio (CAA72735), RtVLG O. mykiss (BAA88059), VAS

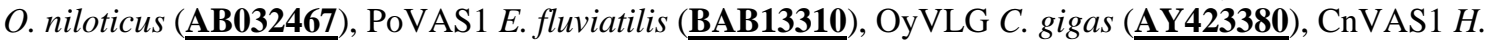
magnipapillata (BAB13307), Ci-DEAD1 C. savignyi (BAA36711), BmVLG B. mori (D86601), VASA D.

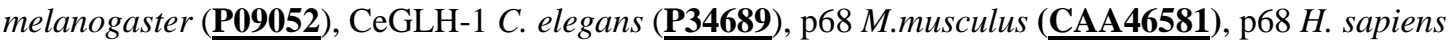
(P17844), PoPL10 E. fluviatilis (BAB13309), PL10 D. rerio (P571016), PL10 M. musculus (AAA39942), DEAD3 M. musculus (Q62167), AN3 D. rerio (24346).

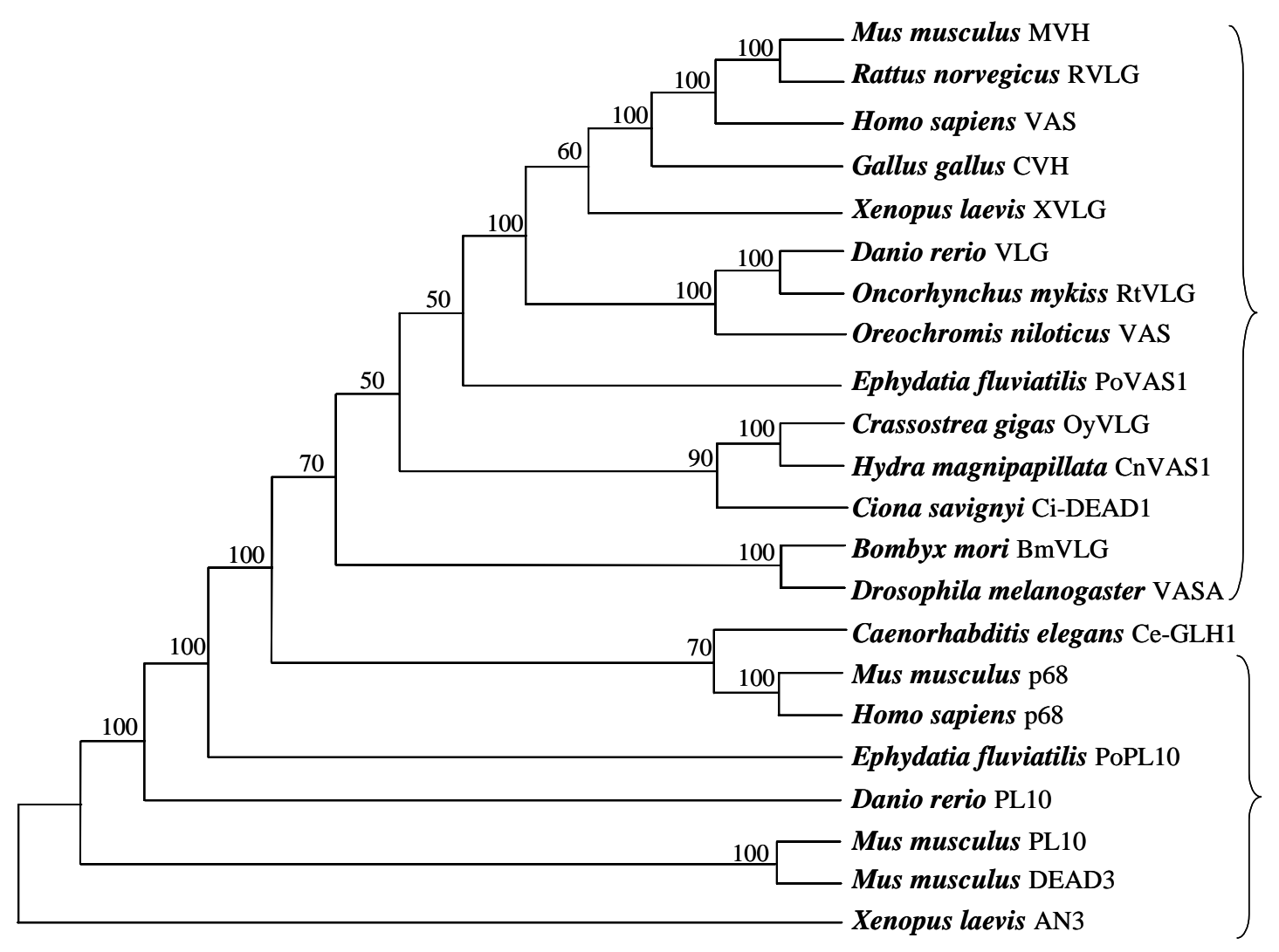

Spatial expression of the presumptive oyster vasa orthologue by RT-PCR

The spatial expression pattern of the presumptive oyster vasa gene was analysed in adult female and male tissues (gills, mantle, adductor muscle, labial palps, gonad, digestive gland) during maturation (April) by RT-PCR. A high level of transcripts was detected in gonad both in females and males, whereas a very low signal or none at all was detected in other tissues 
(See analysis of female tissues in Figure 3). The elongation factor used as positive control was detected in all tissues at the same intensity (Figure 3).

Figure 3. Oyvlg gene expression in female oyster adult tissues. Elongation factor (Felong) was used as positive control.

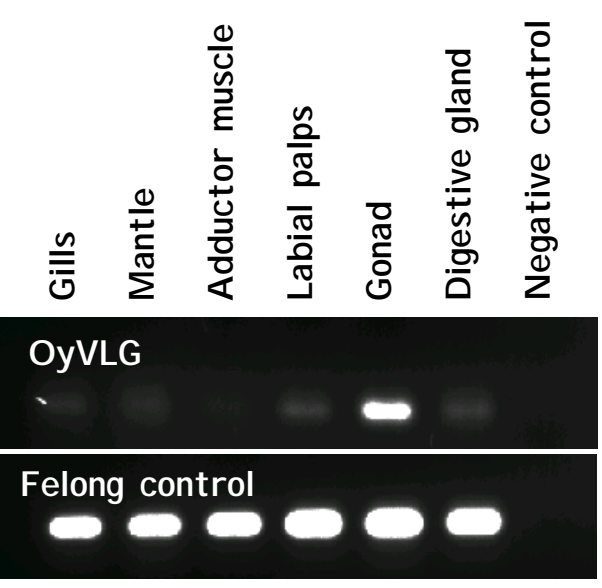

Analysis of C. gigas reproductive cycle by histology and ISH

Key steps of C. gigas gametogenesis in females and males were described by histological observations (Figure 4) and then used to analyse the spatial and temporal expression of the presumptive oyster vasa orthologue gene (Figure 5). Negative ISH control, corresponding to sense probe hybridization, was not stained (Figure 5I). Positive signal, corresponding to antisense probe hybridization, was dark blue staining (Figures 5A-5H').

At the initiation of the reproductive cycle, in February (Figure 4A), gonad consisted of small developing tubules filled with undifferentiated cells, widely separated by connective conjunctive tissue. A strong ISH signal was detected in these small undifferentiated cells, but not in the somatic cell types (hemocytes, conjunctive and digestive gland cells) that 
represented more than 95\% of the slide surface at this stage (Figure 5A). Sex of animals could not be distinguished at this time (Figure 4A).

Figure 4. Histological analysis of C. gigas adult gonad.

Initiation of the reproductive cycle (A) (February); maturation stage in female (B) and male (C) (April); mature female (D) and male (E) (July); female after partial spawning (F) (August); undifferentiated oyster during the

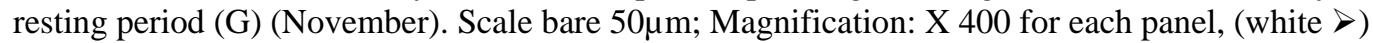
undifferentiated cell; $(\wedge)$ oogonia ; $(*)$ oocytes I; $(\rightarrow)$ mature oocytes; $(\triangleright)$ follicle cell; (white $\wedge$ ) spermatogonia; (white $*$ ) spermatocytes and spermatides; (white $\rightarrow$ ) spermatozoids.
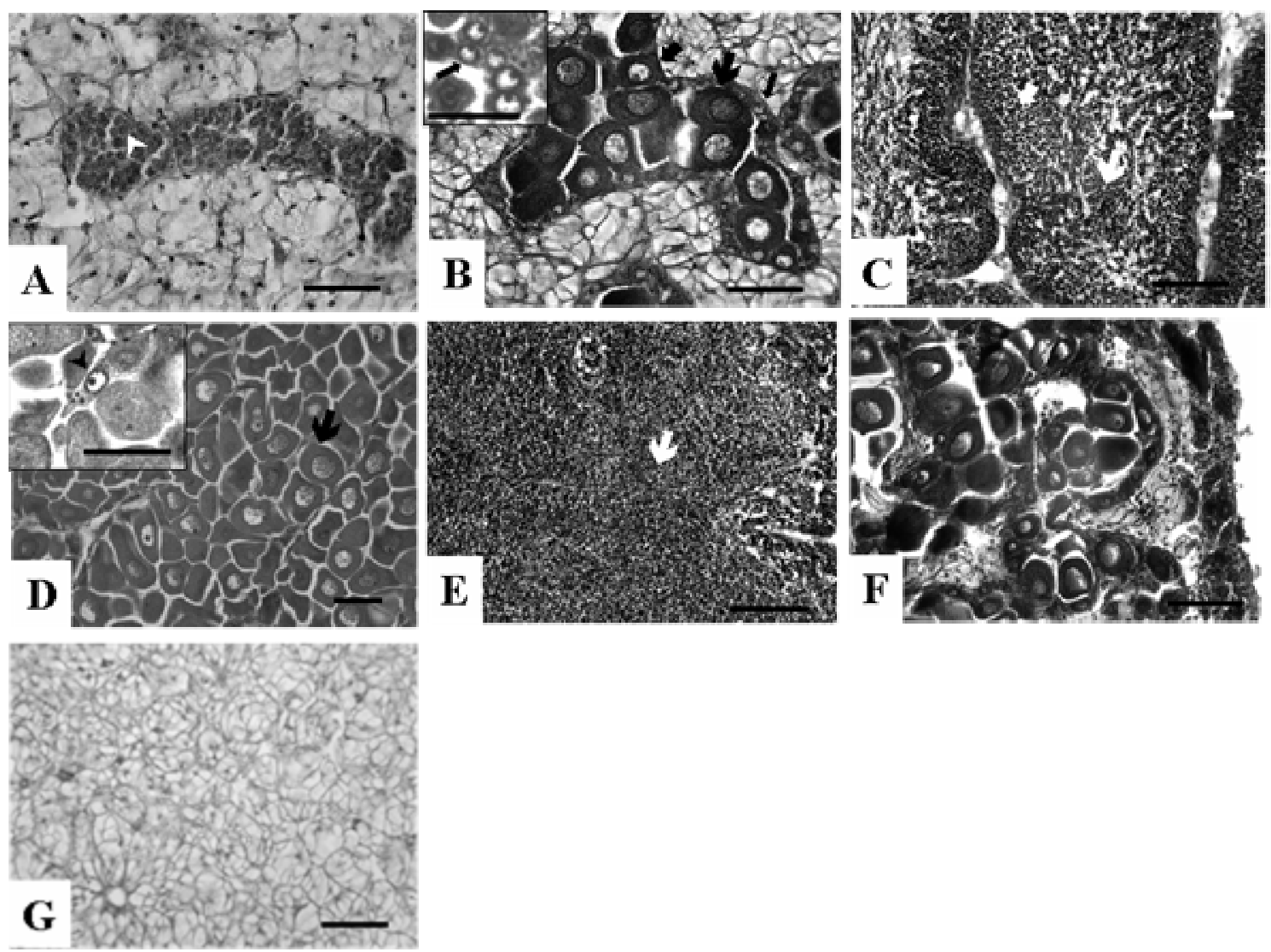

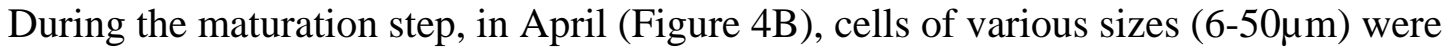
visible in female tubules corresponding to oogonia (cells with compact, large nuclei and a narrow rim of finely granular cytoplasm), oocytes I (larger cells with enlarged nuclei and more coarsely granular cytoplasm) and some vitellogenic oocytes in increasing size order. On the tubule walls, elongated cells appeared close to oocytes (Figure 4D). They were described 
as auxiliary cells in other bivalve species [23]. By ISH, oogonia and auxiliary cells appeared as strongest stained cells (Figure 5B). Staining intensity decreased in oocytes I and became undetectable in vitellogenic oocytes (Figure 5B). In male tubules (Figure 4C, April), cells decreasing in size were arranged in cell layers comprising spermatogonia, spermatocytes I and II, spermatides and spermatozoids from the outer wall to the centre of the tubule (4-2 $\mu \mathrm{m})$. During the male growing phase, a staining gradient was observed in tubules (Figure 5C). The strongest signal was observed in spermatogonia, and intensity progressively decreased toward the centre of the tubules (Figure 5C). At this stage, the occupation rate of the gonad varied between $25 \%$ and $40 \%$ of the visceral mass.

In ripe oysters, (Figure 4D, July), female tubules were filled with mature oocytes (40-50 $\mu \mathrm{m}$ in diameter) with distinct nuclei. Mature oocytes were not stained. Only small cells (oogonia and oocytes I) were stained at the periphery of tubules (Figure 5D). For males, (Figure 4E, July), lumina of tubules were filled with spermatozoids, while germinal epithelia always showed all stages of male germ cells. By ISH, the early stages of male germ cells were stained following the same pattern than during maturation and spermatozoids were not stained (Figure 5E). In mature oysters, gonad represented more than $60 \%$ of the visceral mass.

After partial spawning (Figure 4F, August), female tubules contained oogonia and oocytes I close to the walls of acini, as well as some unspawned mature oocytes or degenerated oocytes (elongated in shape or broken). Oogonia and oocytes I were stained (Figure 5F) and stained patches appeared in the cytoplasm of some residual mature oocytes (Figure 5G). An equivalent signal was observed for males and females except than residual spermatozoids were not stained. The occupation rate of the gonad decreased to fewer than $10 \%$ of the visceral mass after spawning (Figure 4F).

During the resting period (Figure 4G, November), gonadic tubules disappeared. Remaining tissue between mantle and digestive gland was conjunctive tissue composed by 
vesicular storage cells. By ISH, few clusters of undetermined very small cells, scattered in conjunctive tissue, appeared strongly stained (Figures $5 \mathrm{H}$ and $5 \mathrm{H}^{\prime}$ ).

Figure 5. Oyvlg gene expression in adult C. gigas gonad by ISH with an antisense probe. Positive cells are stained in dark blue. Initiation of the reproductive cycle (A) (February); maturation in female (B) and male (C) (April); mature female (D) and male (E) (July); female after spawning (F) (August); female after partial spawning $(\mathrm{G})$ (August); undifferentiated oyster $(\mathrm{H})$ and enlargement of cluster of stem cells (H') during the resting period (November); example of negative control (male mature gonad) (I). Scale bare 50 $\mathrm{mm}$;

Magnification X 400 for each panel, excepted for H' X 1000. Symbols are the same than those used in Figure 4. Residual oocytes $(\rightarrow)$, Cluster of stem cells $(*)$.
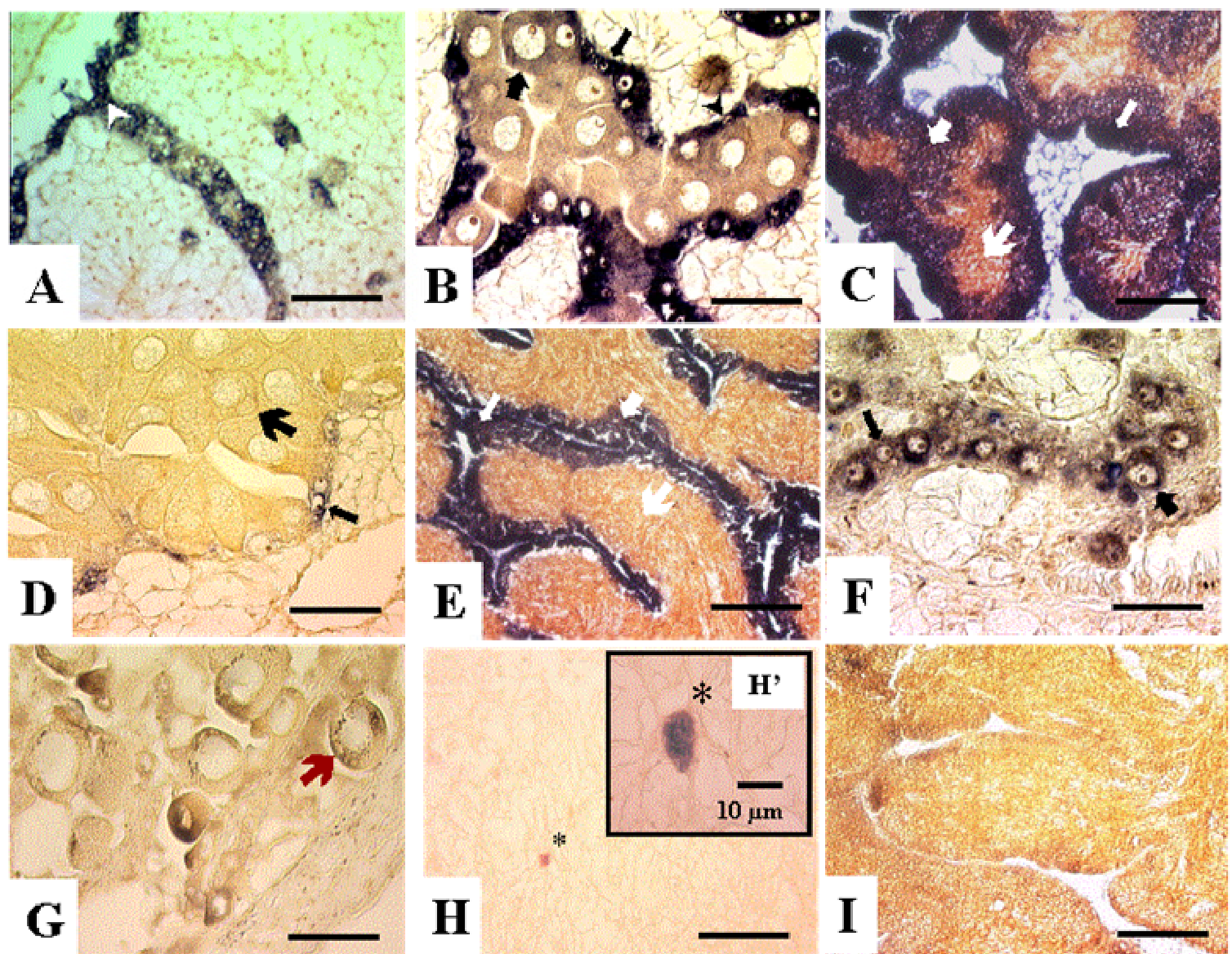

\section{Discussion}

The oyster vasa-like gene (Oyvlg)

VASA is a member of the DEAD-box protein family. All members of this family display eight conserved domains [14]. Four of these eight regions are known to be involved in 
described functions of DEAD-box proteins, and in particular in eIF-4A activity studied by in vitro mutagenesis [24]. These proteins are thought to have ATP-dependent RNA helicase activity, due to ATP-A (AXXGXGKT) and ATP-B (DEAD) motifs, and to participate in RNA unwinding activity, due to the SAT and HRIGR motifs [24]. The deduced amino acid sequence in C. gigas displayed these eight consensus domains, including both ATP-A (AQTGSGKT) and ATP-B (DEAD) motifs and the SAT and HRIGR motifs implicated in RNA helicase function. In the C-terminal region, six of the last eight amino acids are acidic (glutamate or aspartate residues), which is found in several single-stranded nucleic acid binding proteins [5]. A glycine (G)-rich region is present in the $\mathrm{N}$-terminal site as found in number of putative RNA-binding proteins [14]. These data strongly suggest that our characterized oyster sequence encodes a protein member of the DEAD-box family with an ATP-dependent RNA helicase function.

Sequence comparisons and phylogenetic analysis revealed that the oyster DEAD-box protein-like sequence most closely resembles VASA-related proteins rather than other members of DEAD protein family such as PL10 and GLH sub-family members. Phylogenetic analysis showed that OyVLG to be closely related invertebrate VASA-related proteins. This suggests a high degree of conservation during evolution. Our isolated sequence is, therefore, an oyster vasa orthologue. This new oyster gene, designated Oyster vasa-like gene (Oyvlg), is the first vasa-related gene isolated in the Phylum Mollusca.

Oyvlg is specifically expressed in germline cells of C. gigas

ISH analysis with Oyvlg-specific probes showed that Oyvlg is specifically expressed in the adult gonad of both male and female oysters. No expression was detected in somatic tissues. Corroborative results were obtained by RT-PCR, which displayed strong expression of vasa transcripts in gonad compare to weak or none expression in other tissues. These 
experimentations showed that in molluscan as in other phyla examined to date, from "higher" to "lower" metazoans, vasa-related genes are specifically expressed in germline cells $[5,6,8,10-13,25,26]$.

The vasa gene was shown to be expressed in adult germline stem cells in Hydra [8], and in Drosophila [5,10]. High Oyvlg expression was detected in undifferentiated cells of oysters at the initiation of the reproductive cycle and during the resting period (Figures $5 \mathrm{~A}$ and $5 \mathrm{H}^{\prime}$ ). This expression indicates the role of these cells as precursor of germ cells. These cells constitute oyster germinal stem cells.

During gametogenesis, Oyvlg was strongly expressed in oyster auxiliary cells, surrounding oocytes (Figure 5B). Such cells, called auxiliary, follicle or nurse cells, are thought to play a role in oocyte nutrition in bivalves $[23,27]$. Similarly, high levels of vasa transcripts have been detected in nurse cells of Drosophila [5] that provide nutrients and metabolic products to the oocytes (yolk, ribosome, mRNA and protein). In some insects, molluscans, cnidarians or plathelminthes, follicle cells and oocytes arise from a unique cell type, the primordium gonocytes derived from PGCs [28]. In the same way, auxiliary cells and germ cells in oysters could, therefore, have the same origin arising from differentiation of primordium gonocytes. Primordium gonocytes and stem cells previously thought to be two different cell types [4] appeared to be a single cell type.

Oyvlg would be involved in the germline formation in C. gigas

ISH analysis showed that Oyvlg was strongly expressed in the three mitotic germline cell types (stem cells, oogonia, and spermatogonia). Oyvlg expression was also detected in the earliest stages of meiosis, oocytes I and spermatocytes I. In later stages, Oyvlg expression decreased as germ cell maturation proceeded, becoming essentially undetectable in mature oocytes and spermatozoids (Figures 4 and 5). Nevertheless, patches of Oyvlg expression 
detected in cytoplasm of unspawned oocytes after a partial spawning could correspond to maternal expression of vasa in C. gigas. These data and evolutionary conservation observed by phylogenetic analysis suggest that Oyvlg could be involved in the formation of germ cells in oysters as demonstrated in Drosophila [15]. Further functional studies of Oyvlg would be useful to understand the role of this gene and its protein in oyster germline formation.

Renewal and kinetic of development of germ cells in C. gigas

In many organisms, including hydrozoans, nematodes, amphibians, birds, fishes, and mammals, germline stem cells have been described as a self-renewing population of germ cells [2]. They serve as source of gametes throughout the sexually active life of these organisms. For those, which breed seasonally, like oysters, groups of stem cells divide at the beginning of each reproductive period [29]. During the resting period of C. gigas (OctoberNovember), stem cells were scattered in the conjunctive tissue (Figure 5H'). The number of these cells, that strongly expressed Oyvlg, quickly increased when the reproductive cycle was re-initiated in November. These data indicate that in C. gigas, renewal of germ cells result from a proliferation of stem cells, the germinal self-renewing cells.

Different stages of germ cells were observed simultaneously in C. gigas gonadic tubules during gametogensis (Figures 5B and 5C). These results showed that several stem cell proliferation events occur from November to March (in our experimental conditions) to give several cohorts of germ cells. Such a pattern is also observed in sea urchins and some fishes for which stem cells differentiate into germ cells after a defined, species-specific, number of mitotic divisions giving rise to waves of germ cells [2].

In the same way that Oyvlg allowed us to determine the origin of germ cells in adult oysters, it will be a useful molecular marker to elucidate the origin of the germinal stem cells in oyster embryos. 


\section{Acknowledgements}

The authors are grateful to M. Le Pennec (LEMAR, Brest University, France) and J.C. Cochard (LPI, Ifremer Brest, France) for their support during the course of this work. We also acknowledge R. Carnegie (VIMS, Virginia, USA) for his help in editing the English language and J.F. Samain and J. Moal (LPI, Ifremer Brest, France) for their helpful comments on the manuscript. The authors are indebted to P. Favrel, C. Lelong (LBBM, Caen University, France), A. Van Wormhoudt (MNHN, Concarneau, France) and J.Y. Daniel (LPI, Ifremer Brest, France) for technical assistance and sequencing support. The authors are indebted to all staff of the Argenton, La Tremblade and Bouin Ifremer stations for providing and conditioning oysters.

\section{References}

[1] E.E. Saffman, F. Lasko, Germline development in vertebrates and invertebrates, Cell. Mol. Life Sci. 55 (1999) 1141-1163.

[2] H. Lin, The Tao of stem cells in the germline, Annu. Rev. genet. 31 (1997) 455-491.

[3] J.E. Lannan, A.K. Robinson, W.P. Breese, Broodstock management of Crassostrea gigas: II. Broodstock conditioning to maximise larval survival, Aquaculture 21 (1980) 337345.

[4] P. Lubet, P. Herlin-Houtteville, M. Matthieu, La lignée germinale des mollusques pélécypodes. Origine et évolution, Bull. Soc. Zool. France 101 (1976) 22-27.

[5] B. Hay, L.Y. Jan, Y.N. Jan, A protein component of Drosophila polar granules is encoded by vasa and has extensive sequence similarity to ATP-dependent helicases, Cell 55 (1988) 577-587. 
[6] F. Lasko, M. Ashburner, The product of the Drosophila gene vasa is very similar to eucaryotic initiation factor-4A, Nature 335 (1988) 611-617.

[7] D. Roussel, K.L. Bennett, glh-1, a germ-line putative RNA helicase from Caenorhabditis, has four zinc fingers, Proc. Natl. Acad. Sci. USA 90 (1993) 9300-9304.

[8] K. Mochizuki, C. Nishimiya-Fujisawa, T. Fujisawa, Universal occurrence of the vasarelated genes among metazoans and their germline expression in Hydra, Dev. Genes. Evol. 211 (2001) 299-308.

[9] N. Fujimura, K. Takamura, Characterization of an ascidian DEAD-box gene, CiDEAD1 : specific expression in the germ cells and its mRNA localization in the posteriormost blastomeres in early embryos, Dev. Genes. Evol. 210 (2000) 64-72.

[10] T. Komiya, K. Itoh, K. Ikenishi, M. Furusawa, Isolation and characterization of a novel gene of the DEAD Box protein family which is specifically expressed in germ cell of Xenopus laevis, Dev. Biol. 162 (1994) 354 - 363.

[11] L.C. Olsen, R. Aasland, A. Fjose, A vasa-like gene in zebrafish identifies putative primordial germ cells, Mech. Develop. 66 (1997) 95-105.

[12] Y. Fujiwara, T. Komiya, H. Kawabata, M. Sato, H. Fujimoto, M. Furusawa, T. Noce, Isolation of a DEAD-family protein gene that encodes a murine homolog of Drosophila vasa and its specific expression in germ cell lineage, Proc. Natl. Acad. Sci. USA 91 (1994) 1225812262.

[13] D.H. Castrillon, B.J. Quade, T.Y. Wang, C. Quigley, C.P. Crum, The human VASA gene is specifically expressed in the germ cell lineage, Proc. Natl. Acad. Sci. USA 97 (2000) 9585-9590.

[14] S.R. Schmid, P. Linder, D-E-A-D protein family of putative RNA helicases, Mol. Microbiol. 6 (1992) 283-292. 
[15] B. Hay, L.Y. Jan, Y.N. Jan, Localization of vasa, a component of Drosophila polar granules, in maternal-effect mutants that alter embryonic anteroposterior polarity, Development 109 (1990) 425-433.

[16] P. Chomczynski, N. Sacchi, Single step method of isolation by acid guanidium thiocyanate-phenol-chloroform extraction, Anal. Biochem. 162 (1987) 156-159.

[17] A. Huvet, J.Y. Daniel, C. Quéré, S. Dubois, M. Prudence, A. Van Wormhoudt, D. Sellos, J.F. Samain, J. Moal, Tissue expression of two $\alpha$-amylase genes in the Pacific oyster Crassostrea gigas. Effects of two different food rations., Aquaculture 228 (2003) 321-333. [18] Y. Gueguen, J.P. Cadoret, D. Flament, C. Barreau-Roumiguière, A.L. Girardot, J. Garnier, A. Hoareau, E. Bachère, J.M. Escoubas, Immune gene discovery by expressed sequence tags generated from hemocytes of the bacteria-challenged oyster, Crassostrea gigas, Gene 303 (2003) 139-145.

[19] R. Martoja, M. Martoja-Pierson, Initiation aux techniques de l'histologie animale, Masson et Cie, Paris, 1967

[20] C. Montagnani, F. Le Roux, F. Berthe, J.-M. Escoubas, Cg-TIMP, an inducible tissue inhibitor of metalloproteinase from the Pacific oyster Crassostrea gigas with a potential role in wound healing and defense mechanisms, FEBS letters 500 (2001) 64-70.

[21] M.J. Ford, I.A. Anton, D.P. Lane, Nuclear protein with sequence homology to translation initiation factor eIF-4A., Nature 332 (1988) 736-738.

[22] P. Leroy, P. Alzari, D. Sasson, D. Wolgemuth, M. Fellous, The protein encoded by a murine male germ cell-specific transcript is a putative ATP-dependant RNA helicase, Cell 57 (1989) 549-559.

[23] G. Dorange, M. Le Pennec, Ultrastructural study of oogenesis and oocytic degeneration in Pecten maximus from the Bay of St. Brieuc, Mar. Biol. 103 (1989) 339-348. 
[24] A. Pause, N. Sonenberg, Mutational analysis of a DEAD box RNA helicase: the mammalian translation initiation factor eIF-4A, EMBO 11 (1992) 2643-2654.

[25] T. Kobayashi, H. Kajiura-Kobayashi, Y. Nagahama, Differential expression of vasa homologue gene in the germ cells during oogenesis and spermatogenesis in a teleost fish, tilapia, Oreochromis niloticus, Mech. Develop. 99 (2000) 139-142.

[26] H. Nakao, Isolation and characterization of a Bombyx vasa-like gene, Dev. Genes. Evol. 209 (1999) 321-316.

[27] R.K. Pipe, Oogenesis in the marine mussel Mytilus edulis : An ultrastructural study., Mar. Biol. 95 (1987) 405-414.

[28] H. Ruohola, K.A. Bremer, D. Baker, J.R. Swedlow, L.Y. Jan, Y.N. Jan, Role of neurogenic genes in establishment of follicle cell fate and oocyte polarity during oogenesis in Drosophila., Cell 66 (1991) 433-449.

[29] S.J. Morrison, N.M. Shah, D.J. Anderson, Regulatory mechanisms in stem cells biology, Cell 88 (1997) 287-298. 